\title{
Position of railway passenger transport companies on current liberalized transport market
}

\author{
Zdenka Záhumenská ${ }^{1, *}$, Martin Vojtek ${ }^{1}$ and Jozef Gašparík ${ }^{1}$ \\ ${ }^{1}$ University of Žilina, Department of Railway Transport, Univerzitná 1, 01026 Žilina, Slovakia
}

\begin{abstract}
Market liberalization is a great contemporary trend in many fields of economy. Liberalized transport market, where the transport demand is meeting with transport offer, is evolving dynamically. Private railway passenger operators want to increase their market share together with national railway passenger transport companies therefore the quality of passenger transportation is getting higher, which positively influences the attractiveness of railway passenger transport. The article is focused on these current trends of liberalization in railway passenger transport market. From operational and economical point of view, there are described some ways, how to make the railway passenger transport system more effective and make the entire transport system more attractive for traveling public.
\end{abstract}

\section{Introduction}

Passenger transport is generally considered as an activity, which arises as the consequence of spatial division of places, where people are in exact time and their need to move. Requirements for transport of passengers originate in their need to move, while the passenger transport is dependent on the willingness of travelling. [1]

In passenger transport, there are mostly individual passengers, so it is difficult to determine all transport requirements. Passenger transport is divided into individual and public. Individual passenger transport includes walking, cycling and car transport. Public passenger transport includes railway, road, water, air, city and unconventional transport. From spatial point of view, passenger transport is divided into local, regional and long-haul, which is then divided into interregional transport or international transport. [2]

From economical point of view, passenger transport is classified into tertiary sphere - services. It means that there are not any material production values, but it is reflected in costs. In general, passenger transport has got a great social and political importance. Primary function of the transport system is providing transport for passengers on regional, national-interregional and international level. [3]

\section{Railway passenger transport in general}

Key element in railway passenger transport is a customer - passenger, who requires the transport from one place to another. A basic precondition for accomplishing the main requirement - transport, is making the complete offer which provides not only transport, but also other associated services. From economical point of view, very important criterion is the price for transport and it mostly depends on economic indicators. In market economy, there are three factors: costs, demand and competition. [3]

Current trend is to optimize connectivity in railway passenger transport by reduction of transfer time starting at home and finishing in the transport destination. It is important to synchronize arrivals and departures of all connected trains in all points, where passengers can get on, get off and change the vehicle. Minimizing of waiting time will increase quality of passenger transport in general. [4]

Entire quality is defined as an ability to satisfy all requirements of customers. Specific signs for services in transport are insubstantiality, impossibility to store, inseparability, variability, complexity and uniqueness. Level of service quality can be perceived as a disharmony among expectation and perception. Customers - passengers have got different priorities which are connected with quality of service. They usually remember low quality and high quality is a standard for them. The main challenge is to identify the passengers' needs and satisfy them in all cases, because every transport is realized in different conditions. [2]

\section{Liberalization process of railway passenger transport market in the EU}

A basic step in the liberalisation of the railway passenger transport market has been the separation of railway infrastructure managers from railway transport companies (operators respectively carriers) and consequently providing non-discriminatory access of the railway companies to railway infrastructure in all Member States. The partial liberalisation of the railway passenger transport market in the European Union (EU)

* Corresponding author: zdenka.zahumenska@,fpedas.uniza.sk 
was already underway in 2010, when all European railway companies gained access to all railway infrastructures in the EU. Opening up the market to new private railway operators means that several transport operators can compete directly for selected lines at the same time. Given that passenger transport is a State instrument of transport, regional and social policy to provide transport services, it is still largely controlled by the State. [5]

The opening up process of domestic railway passenger transport markets according to the fourth railway package has variety of level in Member States. This process is requested to done not later than 2019, while making public tenders for transport service contracts compulsory, in the public interest. The idea is to meet the objectives of the EU White Paper on transport and The Regulation (EC) No 1370/2007 of the European Parliament and of the Council of 23 October 2007 on public passenger transport services by rail and by road and repealing Council Regulations (EEC) No. $1191 / 69$ and 1107/70. [6]

The current EU transport policy is based on the 'White Paper on the Single European Transport Area Creating a competitive, resource-efficient transport system that includes forty initiatives to create an efficient transport system. The area of the allocation of public services includes an initiative to open up the domestic railway passenger market to competition, including the compulsory award of public service contracts through competitive tendering. The railway transport market has undergone several transformations. Those achieved economic efficiency of rail transport, reducing the financial burden on the state budget, streamlining the management of the railway company and create the conditions for a market orientation. The aim was to increase the flexibility of railway transport to the needs of the customer. The requirements of liberalizing the railway passenger market and harmonizing the conditions for access to this market resulted in the adoption of the so called Fourth Rail Package. [7]

This Regulation lays down the conditions under which competent authorities when imposing or contracting obligations arising from the public service provided by the suppliers pay for costs incurred and/or grant exclusive rights in return for fulfilling the obligations arising from the public service. The Regulation applies to national and international public passenger transport services in rail passenger transport, other passenger rail and road passenger transport. Exceptions are services which are provided mainly for their historical or tourist value. [8-9]

The amended version of the Decree from December 2016 introduced the definition of public service. It is done a public railway passenger transport where they concern transport by rail, with the exception of other track-based modes such as metro or tram. Public service performances are provided by a public or private undertaking for passengers or carriers on the basis of a public service contract concluded between the railway undertaking and the competent public authority or authority with such competence. [8-10]
Contracts are awarded either directly to a selected railway undertaking over which a competent authority control or another possible ways. The competent authority decides itself to provide services in the context of public services in railway passenger transport, and these performances are entrusted to a third party by tender. [11]

The procedure adopted for competitive tendering shall be open to all operators, shall be fair and shall observe the principles of transparency and non-discrimination. Following the submission of tenders and any selection, the procedure may involve negotiations in accordance with these principles in order to determine how best to meet specific or complex requirements. If subcontracting takes place, the operator entrusted with the administration and performance of public passenger transport services in accordance with this Regulation shall be required to perform a major part of the public passenger transport services itself. [12]

A public service contract covering at the same time design, construction and operation of public passenger transport services may allow full subcontracting for the operation of those services. The public service contract shall, in accordance with national and Community law, determine the conditions applicable to subcontracting. Before a public tender is started a decision may be taken by the competent authorities limiting the number of contracts with the same railway undertaking. [8-10]

\section{Comparison of railway passenger transport markets}

The comparison of the basic requirements railway passenger transport contracts according to the way they are entered is dealt with in Table 1.

Table 1. Comparison of the essential requirements according to their assignment.

\begin{tabular}{|c|c|c|c|}
\hline \multirow{2}{*}{\multicolumn{2}{|c|}{ Reqiurements }} & \multicolumn{2}{|c|}{ How to enter the contract } \\
\hline & & $\begin{array}{l}\text { Direct } \\
\text { award }\end{array}$ & $\begin{array}{l}\text { Public } \\
\text { tender }\end{array}$ \\
\hline \multicolumn{2}{|c|}{$\begin{array}{l}\text { Maximum average annual } \\
\text { value of performance }\end{array}$} & $\begin{array}{c}\text { to } 7.5 \text { mil. } \\
€\end{array}$ & $\begin{array}{c}\text { Not } \\
\text { specified }\end{array}$ \\
\hline \multicolumn{2}{|c|}{$\begin{array}{l}\text { Maximum annual amount } \\
\text { of performance }\end{array}$} & $\begin{array}{l}\text { to } 500,000 \\
\text { kilometres }\end{array}$ & $\begin{array}{c}\text { Not } \\
\text { specified }\end{array}$ \\
\hline \multicolumn{2}{|c|}{$\begin{array}{l}\text { Maximum time of the } \\
\text { contract }\end{array}$} & 10 years & 15 years \\
\hline \multirow{3}{*}{$\begin{array}{l}\text { Opportun } \\
\text { ity and } \\
\text { reason for } \\
\text { the } \\
\text { extension } \\
\text { of the } \\
\text { Contract }\end{array}$} & $\begin{array}{l}\text { Depreciation } \\
\text { of assets }\end{array}$ & $\begin{array}{l}\text { yes, } \max \text {. } \\
\text { to } 50 \%\end{array}$ & $\begin{array}{l}\text { yes, } \max \text {. } \\
\text { to } 50 \%\end{array}$ \\
\hline & $\begin{array}{l}\text { Geographica } \\
1 \text { location }\end{array}$ & no & $\begin{array}{l}\text { yes, } \max . \\
\text { to } 50 \%\end{array}$ \\
\hline & $\begin{array}{l}\text { Amortizatio } \\
n \text { of capital }\end{array}$ & no & $\begin{array}{c}\text { yes, } \\
\text { necessary } \\
\text { justification }\end{array}$ \\
\hline \multicolumn{2}{|c|}{$\begin{array}{l}\text { Obligation to publish a } \\
\text { pre-announcement in the } \\
\text { EU Bulletin for an output } \\
\text { range of } 50,000 \\
\text { kilometres or more }\end{array}$} & $\begin{array}{c}\text { yes, } 1 \text { year } \\
\text { before } \\
\text { direct } \\
\text { awarding }\end{array}$ & $\begin{array}{c}\text { yes, } 1 \text { year } \\
\text { before starts } \\
\text { public } \\
\text { tendering }\end{array}$ \\
\hline
\end{tabular}


Secondary law of EU affects the allocation of public service performance, in particular in terms of the level of quality of service provided, are the Technical Standard EN 13816 'Transport, Logistics and services, Public passenger transport, Definitions, objectives and measurement of service quality' as well EN 15140 'Public passenger transport, Essential requirements and recommendations for systems to measure service quality'.

Regulation No. 1370/2007 EC governs the general conditions applicable to the Public Service Contract the procurement, content and reimbursement of services provided under the Treaties. The precise public procurement rules for the award of public service contracts are not specified in the Regulation and remain within the competence of the Member States. [11]

Examples of countries conducting tenders for the allocation of performance in rail passenger transport are shown in Table 2. [15]

Table 2. European countries, that realized public tenders for allocation of performance in railway passenger transport.

\begin{tabular}{|l|c|c|c|}
\hline \multicolumn{1}{|c|}{ Country } & $\begin{array}{c}\text { Public } \\
\text { Tender }\end{array}$ & $\begin{array}{c}\text { Direct } \\
\text { contracting }\end{array}$ & $\begin{array}{c}\text { Administration } \\
\text { monopoly }\end{array}$ \\
\hline Belgium & & $\mathrm{x}$ & \\
\hline Bulgaria & & $\mathrm{x}$ & \\
\hline Czechia & & $\mathrm{x}$ & \\
\hline Denmark & $\mathrm{x}$ & $\mathrm{x}$ & \\
\hline Germany & $\mathrm{x}$ & $\mathrm{x}$ & \\
\hline Estonia & & $\mathrm{x}$ & \\
\hline Ireland & & $\mathrm{x}$ & \\
\hline Greece & & $\mathrm{x}$ & \\
\hline Spain & & $\mathrm{x}$ & \\
\hline France & & $\mathrm{x}$ & $\mathrm{x}$ \\
\hline Italy & $\mathrm{x}$ & $\mathrm{x}$ & \\
\hline Latvia & & $\mathrm{x}$ & \\
\hline Lithuania & & $\mathrm{x}$ & \\
\hline Luxembourg & & $\mathrm{x}$ & \\
\hline Hungary & & $\mathrm{x}$ & \\
\hline Netherlands & $\mathrm{x}$ & & $\mathrm{x}$ \\
\hline Austria & & $\mathrm{x}$ & $\mathrm{x}$ \\
\hline Poland & $\mathrm{x}$ & $\mathrm{x}$ & $\mathrm{x}$ \\
\hline Portugal & $\mathrm{x}$ & $\mathrm{x}$ & \\
\hline Romania & & $\mathrm{x}$ & \\
\hline Slovenia & & $\mathrm{x}$ & \\
\hline Slovakia & & $\mathrm{x}$ & \\
\hline Finland & & $\mathrm{x}$ & \\
\hline Sweden & $\mathrm{x}$ & & \\
\hline Great Britain & $\mathrm{x}$ & & \\
\hline & & \\
\hline & & & \\
\hline & & & \\
\hline
\end{tabular}

Outsourcing tenders in the Member States may be at varying levels of state administration as well as can vary the conditions of operation of public tenders. Requirements for safety and interoperability must be common to all Member States with regard to the common EU legislation and technical specifications for interoperability (TSI).

\section{Economic aspects of railway passenger transport}

Railway passenger transport has to be evaluated from economical point of view. Basic evaluation method is operating costs calculation. Costs are financial representation of company sources consumption for realizing services per time. Internal costs of the transport company arise from operation of trains on railways. Thanks to calculation, the exact amount of these costs is known. In railway passenger transport, the calculation unit is the service - transporting of passengers. It can be defined by quantity (number of trains, vehicles), time (staff working time, time of traveling) or other way (passenger-kilometers, train-kilometers). [16]

In general, there are these costs: vehicle costs (price for vehicle, repairs and maintenance, insurance, operational cleaning), railway infrastructure access, staff costs (wages of vehicle-drivers and stewards), traction energy consumption and other indirect costs (management, marketing, travel ticket selling system, information system etc.). Sum of all costs, which are converted to one typified train on the route, is the base for making the tariff charges. [14]

Railway vehicle costs are calculated this way:

$$
r_{\text {trhm }}^{\text {RV }} \frac{D_{Y}+2 R M_{Y}+O C_{Y}+I N S_{Y}}{\emptyset \text { annual vehicle kilometrage }}
$$

where: $\quad r^{R V}{ }_{t r k m}$ - railway vehicle costs rate for trainkilometre [€/trkm], $D_{Y}$-depreciation of vehicle per year $[€]$, $\Sigma R M_{Y}$ - entire costs for repairs and maintenance of vehicle per year $[€]$,

$O C_{Y}$ - entire costs for operational cleaning of vehicle per year $[€]$,

$I N S_{Y}$ - entire costs for vehicle insurance per year $[€]$,

$\varnothing$ annual vehicle kilometrage - average kilometrage of railway vehicle per year $[\mathrm{km}]$.

$$
C_{R V}=\Sigma t r k m \cdot r_{\text {trkm }}^{R V} \cdot N R V_{t y}
$$

where: $C_{R V}$ - entire railway vehicle costs per route [€],

$\Sigma$ trkm - sum of train-kilometres per route, $r^{R V}{ }_{t r k m}$ - railway vehicle costs rate for trainkilometre $[€ /$ trkm],

$N R V_{t r}$ - number of railway vehicles in the train on the route [vehicles].

Staff costs are calculated this way [14]:

$$
r_{\text {emph }}^{s}=\frac{\text { price for working }+ \text { equipment }}{\Sigma \text { work time }}
$$

where: $r_{\text {emph }}^{S}-$ staff costs rate for employee-hour [€/emph],

price for working - all month company's costs for the employee [€],

equipment - month costs for equipment of employee [€],

$\Sigma$ work time - entire month work time of employee [hours]. 


$$
C_{s}=t_{y} \cdot C R_{s} \cdot s_{\text {emph }}^{s}
$$

where: $C_{S}-$ staff costs per route $[€]$,

$t_{r}$ - train ride time [hours],

$C R_{S}-$ conversion ratio: train ride time

$\rightarrow$ employee-hour,

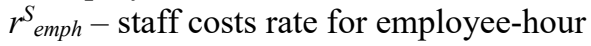

[€/emph].

Traction energy consumption costs are calculated this way [14]:

$$
C_{T E C}=\frac{\Sigma g t k m \cdot m c_{T E} \cdot s_{T E}}{1000}
$$

where: $C_{T E C}-$ entire traction energy consumption costs per route [€],

$\Sigma$ gtkm - gross-tons-kilometres per route, $m c_{T E}$ - measurable consumption of traction energy per thousand gross-tons-kilometres, $r_{T E}$ - traction energy rate $[€]$.

From operating costs calculation, tariff rates can be appointed. The tariff reflects valuable relations among the operator and passengers. These rates have to include internal goals of the operator (increasing profit, decreasing costs, market share etc.), social sphere (quality and offer of public transport, reducing regional gaps etc.) and environmental aspects. Current transport demand and complementary transport offer are also important part of setting tariff rates.

Application of economic aspects of operating passenger trains from transport company point of view is described in case study of fictional Express train from Bratislava to Bardejov in Slovakia. Firstly, according to previous formulas, there is a summary of operating costs calculation shown in table 3 .

Table 3. Operating costs per one fictional train.

\begin{tabular}{|l|c|c|}
\hline \multicolumn{3}{|c|}{ COSTS (€) } \\
\hline vehicle & 1051.76 & $26.61 \%$ \\
\hline infrastructure & 649.18 & $16.42 \%$ \\
\hline vehicle-driver & 190.88 & $4.83 \%$ \\
\hline stewards & 184.38 & $4.66 \%$ \\
\hline traction energy & 888.74 & $22.48 \%$ \\
\hline indirect & 988.31 & $25.00 \%$ \\
\hline sum & $\mathbf{3 9 5 3 . 2 4}$ & $100.00 \%$ \\
\hline converted to one seat & 12.35 & \\
\hline converted to one placekm & 0.023265 & \\
\hline
\end{tabular}

Comparison of costs and revenues are shown in table 4. When the result $>0 \rightarrow$ operation of passenger trains is economically effective. On the other hand, when the result $\leq 0 \rightarrow$ operation of passenger trains is not economically effective therefore the transport company would find some way how to reduce costs or increase revenues. Some government subsidies are also one of possible ways how to make operation of passenger trains economically effective.
Table 4. Economic effectiveness of fictional train on the route.

\begin{tabular}{|l|c|c|}
\hline \multicolumn{3}{|c|}{ Route: BRATISLAVA - BARDEJOV } \\
\hline $\begin{array}{l}\text { Sum of costs per one } \\
\text { typified train }\end{array}$ & 3953.24 & $\begin{array}{c}€ \text { without } \\
\text { VAT }\end{array}$ \\
\hline $\begin{array}{l}\text { Costs converted to one } \\
\text { seat }\end{array}$ & 12.35 & $\begin{array}{c}€ \text { without } \\
\text { VAT }\end{array}$ \\
\hline $\begin{array}{l}\text { Sum of revenues per one } \\
\text { typified train }\end{array}$ & 5210.00 & $€$ with VAT \\
\hline minus VAT & 4168.00 & $\begin{array}{c}€ \text { without } \\
\text { VAT }\end{array}$ \\
\hline $\begin{array}{l}\text { Result (revenues minus } \\
\text { costs) }\end{array}$ & $\mathbf{2 1 4 . 7 6}$ & $€$ \\
\hline
\end{tabular}

The case study indicates that it is economically effective to operate trains on this route according to proposed conditions, which are not specified above. It shows the way how to consider operation of trains on new routes. Transport companies must consider enormous number of factors and conditions, which are necessary for objective and accurate assessment of providing railway passenger transport services.

\section{Conclusion}

The process of railway passenger market liberalization influences contemporary progression in the whole passenger transport system. There are several ways how to evaluate this process, because it has got different consequences to traveling public and transport companies, which also vary in each country according to its legislation and economic conditions. Market share growth of private transport companies is a basic result of liberalization and it is proportionally connected with improvement of transport qualitative criteria and increasing attractiveness of railway passenger transport. Private transport companies are focused on costs optimization and making higher profit therefore railway passenger transport market is significantly affected by economical aspects. These aspects are mainly internal costs, transport demand and level of competitiveness. In central Europe, there are some private railway passenger transport companies with different strategies. The most famous are WEST Bahn (Austria), Regio Jet (Czech Republic, Slovakia, Austria), LEO Express (Czech Republic, Slovakia), ARRIVA vlaky (Czech Republic, Slovakia). These companies provide also bus services, which is partially complement to their trains.

The paper is supported by the VEGA Agency under Project 1/0095/16, 'Assessment of the quality of connections on the transport network as a tool to enhance the competitiveness of public passenger transport system' 


\section{References}

1. Z. Záhumenská, V. Gáborová, J. Gašparík, Perner's contacts, 12, 1. 174-185 (2017)

2. J. Gašparík, O. Stopka, L. Pečený, Our sea, 62.3 SI. 114-118 (2015)

3. L. Černá, A. Dolinayová, J. Daniš, Transport Means, 414-419 (2016)

4. J. Gašparík, V. L’upták, P. Meško, ICTTE, 388-392 (2016)

5. L. Pečený, J. Gašparík, V. Gáborová, ICTTE, 462466 (2016)

6. J. Gašparík, P. Meško, Z. Záhumenská, Periodica Polytechnica Transportation Engineering Onlinefirst. 6 (2018)

7. R. Kampf, O. Stopka, I. Kubasakova, V. Zitricky. World Multidisciplinary Civil EngineeringArchitecture-Urban Planning Symposium. (2016) DOI: 10.1016/j.proeng.2016.08.623.

8. A. Dolinayová, M. Loch, J. Čamaj, Transportation research procedia, 916-925 (2016)

9. REGULATION (EC) No 1370/2007 OF THE EUROPEAN PARLIAMENT AND OF THE COUNCIL No. 1370/2007 of 23 October 2007 on public passenger transport services by rail and by road and repealing Council Regulations (EEC) Nos 1191/69 and 1107/70, 13 (2007)

10. P. Blaho, P. Sulko, L. Cerna. LOGI proceeding, MATEC, 134. (2017
11. M. Poliak. Ekonomicky casopis. 61, 2. 206-220. (2013)

12. REGULATION (EU) 2016/2338 OF THE EUROPEAN PARLIAMENT AND OF THE COUNCIL of 14 December 2016 amending Regulation (EC) No 1370/2007 concerning the opening of the market for domestic passenger transport services by rail, (2016)

13. COMMISSION STAFF WORKING DOCUMENT Accompanying the White Paper - Roadmap to a Single European Transport Area - Towards a competitive and resource efficient transport system, 32 (2011)

14. J. Čamaj, J. Mašek, M, Kendra, Transport Means, 147-151 (2015)

15. L. Černá, V. Zitrický, J. Ponický, Mathematical methods in economics, 126-131 (2016)

16. M. Kvizda, Rewiew of Economick Perspectives. 16. 4. 389-394. (2016)

17. A. Dolinayová, E. Nedeliaková, Controlling in railway transport, 148 (2015)

18.

19. A. Torok. Procedia Engineering 187, 722-725, (2017), https://doi.org/10.1016/j.proeng.2017.04.446

20. L. Černá, V. Zitrický, J. Ponický.. Mathematical methods in economics $=$ MME. 126-131.(2016). 